Безтелесна Л. І., А.е.н., професор, Прокопчук Н. М., магістр з управління персоналом і економіки праці (Національний університет водного господарства та природокористування, м. Рівне)

\title{
СОЦІАЛЬНО-ЕКОНОМІЧНА ДОЦІЛЬНІСТЬ ЗАСТОСУВАННЯ МАРКЕТИНГУ ПЕРСОНАЛУ В СТРАТЕГІЧНОМУ УПРАВЛІННІ ПІДПРИЕМСТВОМ
}

Відображено соціально-економічну доцільність застосування маркетингу персоналу на одному із підприємств лісового господарства. Проаналізовано витрати та шляхи покриття потреби у персоналі за рахунок власних джерел. Побудований практичний механізм реалізації маркетингу персоналу, що включає налагодження мережевої взаємодії підприємства і навчальних закладів, формування картки індивідуального професійного розвитку працівника, побудову планів професійного зростання персоналу.

Ключові слова: персонал, маркетинг, підприємство, картка індивідуального професійного розвитку, мережева взаємодія, кадровий потенціал, кадровий резерв, планування.

Постановка проблеми. У сучасних умовах необхідність маркетингової діяльності в управлінні персоналом підприємства обумовлена об'єктивною потребою раціонально планувати, розподіляти, використовувати і розвивати людські ресурси, забезпечувати найсприятливіші умови для професійного зростання працівників, управляти процесом мотивації їхньої трудової поведінки. Для багатьох керівників стає очевидним той факт, що забезпечення підприємства кваліфікованим персоналом, формування ефективної команди $€$ досить складним завданням, вирішення якого вимагає спеціальних знань і навичок. I хоча маркетингом персоналу тепер зацікавилася велика кількість економістів-менеджерів з персоналу, психологів та інших вчених, але він все ще не знайшов однозначного розуміння і чітких характерних рис його практичної реалізації.

Аналіз досліджень і публікацій. Дослідженню сутності, понятійних елементів, організаційних підходів до визначення складу та змісту завдань маркетингу персоналу присвячені праці Л. Балабанова, В. Воронкової, В. Колпакова, В. Кармазіна та інших.

Невирішені раніше частини загальної проблеми. Проведений аналіз уже існуючих наукових праць з питань маркетингу персоналу 
дає право стверджувати, що нині актуальним $€$ не лише поглиблення його концептуальних основ, але й в частині практичного застосування інструментів управління персоналом підприємства на засадах маркетингу.

Постановка завдання. Метою статті $\epsilon$ теоретико-методичне та практичне обґрунтування соціально-економічної доцільності застосування маркетингу персоналу в управлінні підприємством, а особливо на успішних у фінансовому плані державних підприємствах, зокрема, лісового господарства.

Основні результати дослідження. Маркетинг персоналу - вид управлінської діяльності, спрямованої на довгострокове забезпечення організації людськими ресурсами. Ці ресурси утворюють стратегічний потенціал, за допомогою якого можливе вирішення конкретних цільових завдань [1]. Практичне застосування маркетингу персоналу на підприємстві вимагає здійснення витрат, які можна класифікувати на: з одного боку, на зовнішні та внутрішні, з іншого - одночасні й поточні [2] (рис. 1).

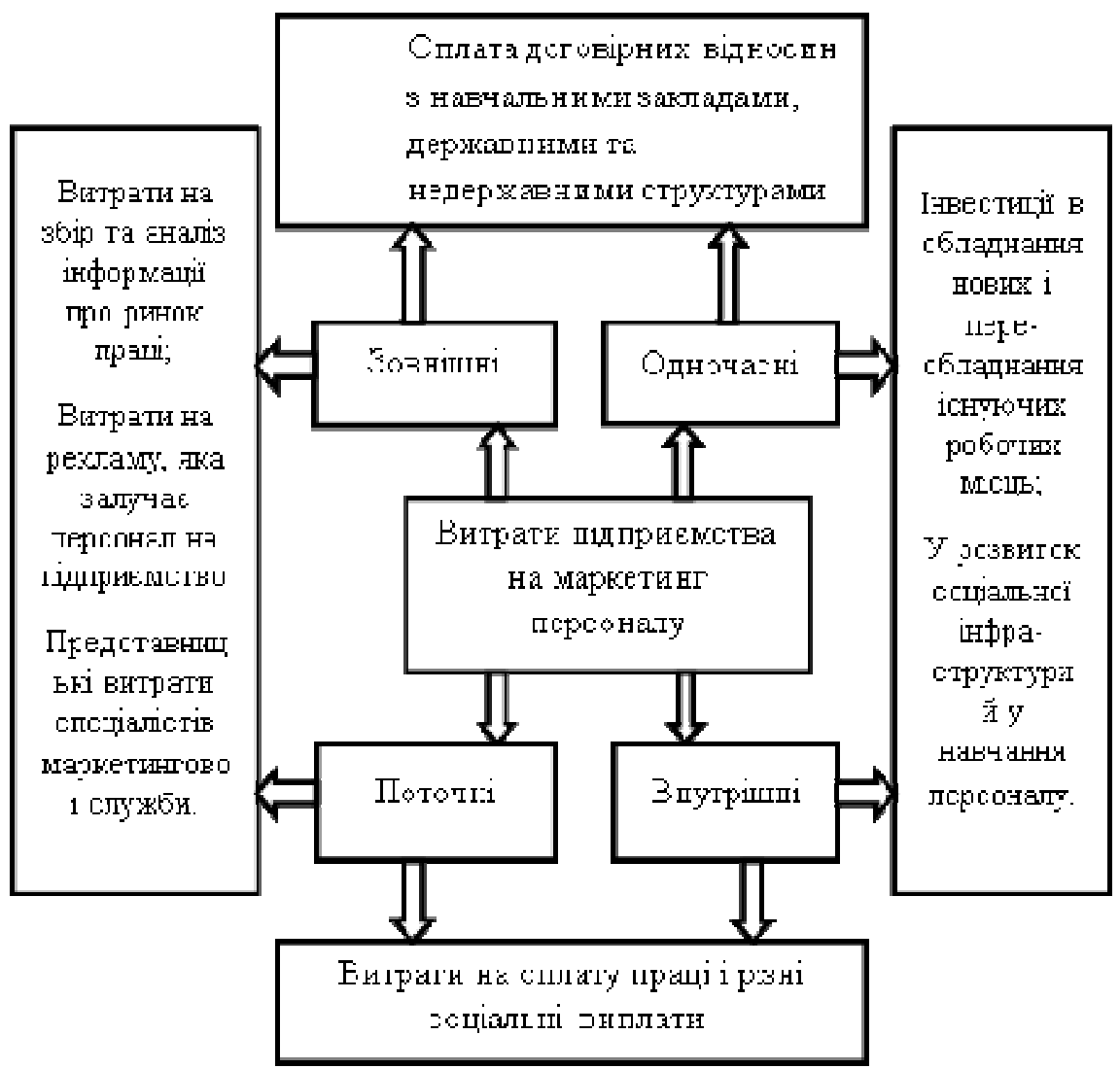

Рис. 1. Класифікація витрат підприємства на маркетинг персоналу 
Джерелами покриття потреб у персоналі є:

- різні навчальні заклади й центри;

- центри забезпечення зайнятості;

- компанії з підбору персоналу;

- різні професійні асоціації й об'єднання;

- особисті і родинні зв'язки;

- вільний ринок праці;

- підприємства, на яких працюють необхідні спеціалісти;

- власні внутрішні джерела.

Шляхи покриття потреб у персоналі будуть різними в залежності від того, за рахунок зовнішніх або внутрішніх джерел воно здійснюється.

Усе різноманіття шляхів покриття за рахунок зовнішніх джерел розділяється на активні і пасивні (рис. 2).

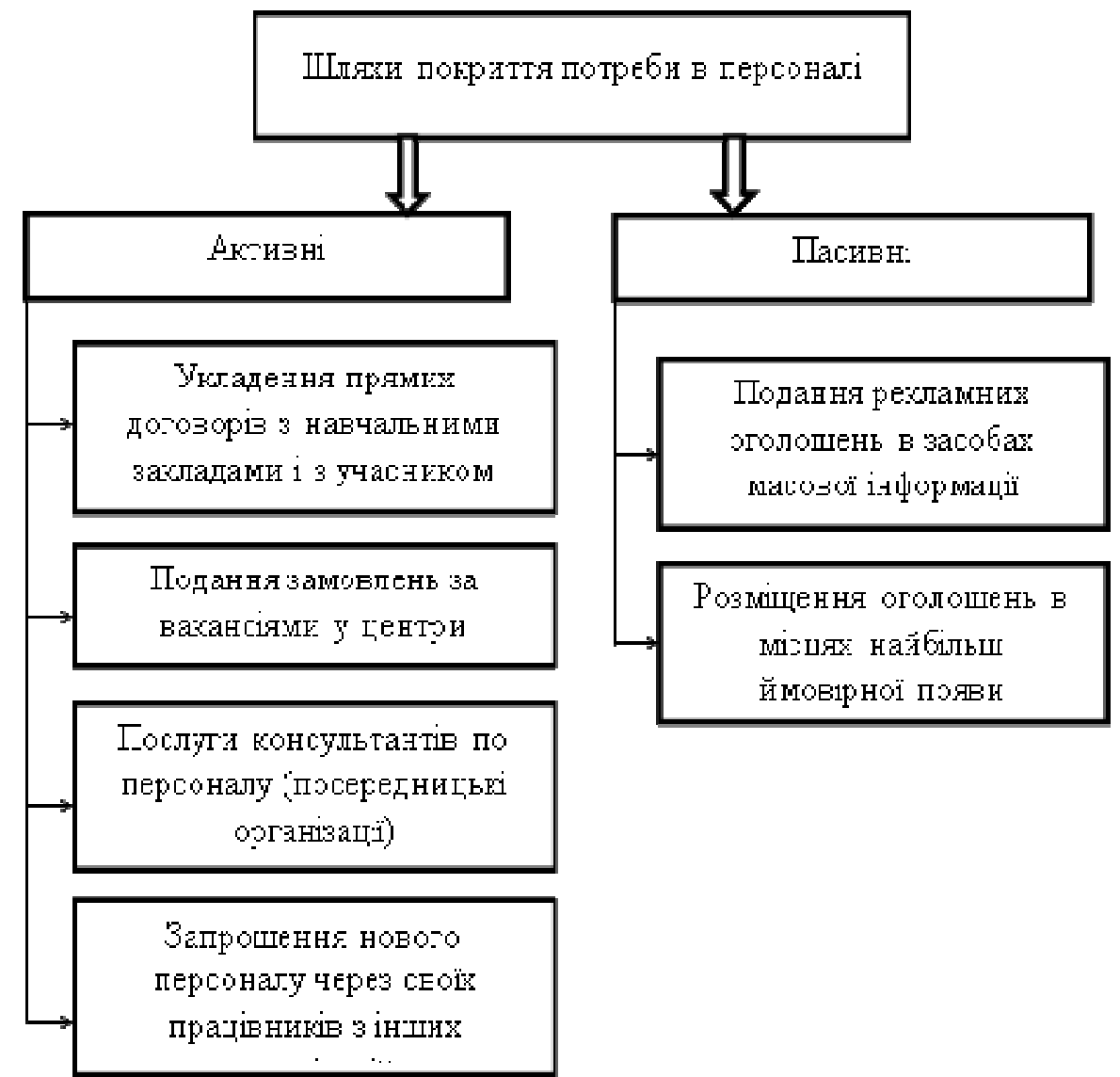

Рис. 2. Шляхи покриття потреб у персоналі

Шляхами покриття потреб у персоналі за рахунок власних (внутрішніх) джерел $є$ : 
1) переміщення працівників з одного підрозділу до іншого;

2) переміщення працівників на більш високі ієрархічні рівні;

3) формування нової організаційно-функціональної ролі працівника на колишньому робочому місці.

Необхідно зазначити, що у всіх трьох випадках виникає необхідність додаткового навчання працівників [3].

На підприємстві завжди існує прогнозований чи непрогнозований рух персоналу, що обумовлює прийняття стратегічних управлінських рішень. Звісно, що реалізація кожної дії у відношенні до персоналу потребує ресурсів. Тому проектування всіх управлінських рішень щодо персоналу розпочинається із аналізу виконання виробничої програми та економічних результатів діяльності підприємства.

Проведена економічна оцінка реалізації виробничої програми ДП «Березнівський лісгосп» свідчить, що впродовж досліджуваного періоду на ньому було досягнуто добрих результатів (табл. 1).

Таблиця 1

Економічна оцінка діяльності ДП «Березнівський лісгосп» [4]

\begin{tabular}{|l|c|c|c|c|c|}
\hline \multicolumn{1}{|c|}{ Показник } & \multirow{2}{*}{$\begin{array}{c}\text { Одиниці } \\
\text { виміру }\end{array}$} & \multicolumn{3}{|c|}{ Роки } & \multicolumn{1}{|c|}{$\begin{array}{c}\text { Темп } \\
\text { зрос- } \\
\text { тання,\% }\end{array}$} \\
\cline { 5 - 6 } $\begin{array}{l}\text { Обсяги реалізованої } \\
\text { продукції/наданих по- } \\
\text { слуг (у факт. цінах) }\end{array}$ & тис.грн. & 51264 & 76777 & 93348 & 182,1 \\
\hline $\begin{array}{l}\text { Середньооблікова чи- } \\
\text { сельність працівників }\end{array}$ & осіб & 289 & 272 & 255 & 88,2 \\
\hline $\begin{array}{l}\text { Продуктивність праці } \\
\text { одного працівника }\end{array}$ & грн./ос. & 177,38 & 282,27 & 366,07 & 206,4 \\
\hline $\begin{array}{l}\text { Фінансовий результат } \\
\text { до оподаткування }\end{array}$ & тис.грн. & 1458 & 3293 & 4745 & 325,4 \\
\hline $\begin{array}{l}\text { Чистий прибуток (зби- } \\
\text { ток) }\end{array}$ & тис.грн. & 732 & 2353 & 3403 & 464,9 \\
\hline $\begin{array}{l}\text { Рентабельність реалі- } \\
\text { зованої продукції }\end{array}$ & \% & 1,4 & 3,1 & 3,6 & 257,1 \\
\hline
\end{tabular}

Основними тенденціями у діяльності підприємства $є$ зростання обсягу реалізованої продукції, продуктивності праці, прибутковості та рентабельності реалізованої продукції.

Проте фінансово-економічний успіх підприємства $€$ результатом діяльності його персоналу. Для забезпечення і в майбутньому високих результатів діяльності підприємства варто ділову стратегію ув'язувати зі стратегією управління персоналом. Окрім того, здійс- 
нювати моніторинг останньої. Традиційно для цієї мети використовують показники руху персоналу (табл. 2).

Проведений моніторинг реалізації стратегії управління персоналом свідчить, що на підприємстві реалізується споживацька стратегія. Саме відбувається експлуатація підприємством трудового потенціалу працівників, а персонал задовольняє свої потреби, використовуючи можливості підприємства. Проте їх спільного розвитку не відбувається.

Для поглибленого виявлення категорії персоналу, що найчастіше вивільняється з підприємства були опрацьована внутрішня документація і виявлено, що найбільше вивільняються чоловіки у віці 15-35 років, що мають неповну та базову вищу освіту та працюють робітниками. Отож, можна констатувати факт, що на підприємстві не займаються маркетингом власного персоналу, а саме його розвитком за рахунок навчань, перепідготовки та підвищення кваліфікації. Саме реалізуючи заходи маркетингу персоналу щодо власних працівників, підприємство може збудувати ефективне управління персоналом.

Таблиця 2

Динаміка показників механічного рух персоналу ДП «Березнівський лісгосп», осіб [5]

\begin{tabular}{|l|c|c|c|c|}
\hline \multirow{2}{*}{ Назва показника } & \multicolumn{3}{c|}{ Роки } & Темп зро- \\
\cline { 2 - 4 } & 2014 & 2015 & 2016 & стання, \% \\
\hline $\begin{array}{l}\text { Середньооблікова чисельність } \\
\text { працівників }\end{array}$ & 289 & 272 & 255 & 88,2 \\
\hline Прийнято на роботу & 30 & 29 & 23 & 76,7 \\
\hline $\begin{array}{l}\text { Вибуло, усього (з причин плинно- } \\
\text { сті) }\end{array}$ & 37 & 68 & 59 & 159,4 \\
\hline Коефіцієнт обороту по прийому & 0,10 & 0,11 & 0,09 & 90,0 \\
\hline Коефіцієнт обороту по звільненню & 0,13 & 0,25 & 0,23 & 176,9 \\
\hline Коефіцієнт загального обороту & 0,23 & 0,36 & 0,32 & 139,1 \\
\hline Коефіцієнт плинності кадрів & 0,13 & 0,25 & 0,23 & 176,9 \\
\hline
\end{tabular}

Основним завданням удосконалення маркетингу персоналу в ДП «Березнівський лісгосп» є підвищення його якості, а саме: використання активних шляхів покриття потреби в персоналі за рахунок власних (внутрішніх) джерел, налагодження співпраці з навчальними закладами та проведення первинної підготовки працівників і розробка планів з розвитку персоналу.

Завданням планування розвитку персоналу є визначення май- 
бутніх вимог, що ставляться до робочих місць, а також планування заходів, необхідних для професійного розвитку працівників.

У плануванні розвитку персоналу важливим завданням $є$ планування заходів, спрямованих на досягнення рівня освіти, необхідного для призначення на певну посаду. Це обумовлює формування планів щодо подальшої освіти працівників, скерування їх для набуття спеціальної професійної кваліфікації і виробничого досвіду.

Потреба в розвитку персоналу визначається через порівняння знань і вмінь працівників з майбутніми завданнями і вимогами. При цьому необхідно враховувати інтереси і побажання працівника, а також його потенціал. Працівники зацікавлені в пристосуванні своєї кваліфікації до вимог робочого місця, в гарантіях виробничого зростання (планування кар'єри): підвищення особистої мобільності на ринку робочої сили; отримання шансів для самореалізації на робочому місці.

Розвиток персоналу для кожного підприємства є важливим напрямом виробничих інвестицій. Пріоритетність інвестицій в розвиток персоналу визначається необхідністю підвищення ділової активності кожного працівника з метою подальшого успішного розвитку організації, упровадження нових технологій, зростання продуктивності праці тощо.

Якість персоналу підприємства $є$ одним з головних факторів, який обумовлює темпи розвитку підприємства, зростання його конкурентних переваг, зростання ефективності діяльності підприємства в цілому.

Проведений моніторинг реалізації стратегій ділової і управління персоналом для ДП «Березнівський лісгосп» дає право стверджувати, що доцільною $є$ наразі розробка комплексної програми розвитку персоналу.

Розпочати формування комплексної програми розвитку персоналу варто з оцінки кадрового потенціалу.

Кадровий потенціал - це трудові можливості підприємства, здатність персоналу до генерування ідей, створення нової продукції, його освітній, кваліфікаційний рівень, психофізіологічні характеристики і мотиваційний потенціал [6].

Кадровий потенціал підприємства характеризується такими кількісними та якісними показниками [7]:

а) кількісні показники:

- чисельність працівників;

- професійно-кваліфікаційний склад кадрів;

- статевий склад;

- середній вік працівників; 
- стаж роботи на підприємстві в цілому і на певній посаді;

- укомплектованість підприємства кадрами та ін.;

б) якісні показники:

- індивідуально-кваліфікаційний потенціал кожного працівника (професійні характеристики);

- індивідуальні професійні характеристики (професійний досвід, соціально-психологічні особливості особистості, конкурентоспроможність працівника);

- соціально-психологічні й організаційні параметри групової динаміки: групова згуртованість, соціально-психологічний клімат, організаційна культура та цінності підприємства тощо.

Саме проведення оцінки кадрового потенціалу підприємства є основою для формування кадрового резерву.

Кадровий резерв - це група керівників і спеціалістів, що володіють здатністю до управлінської діяльності, що відповідають вимогам, пройшли процедуру добору і систематичну цільову кваліфікаційну підготовку.

Розпочати процес практичного впровадження маркетингу персоналу на підприємстві варто через запровадження системи карток індивідуального професійного розвитку, що дасть змогу зробити процес перепідготовки та підвищення кваліфікації спеціалістів всеохоплюючим та якісним.

Саме керівникам служб, відділів і підрозділів підприємства потрібно завести на кожного спеціаліста картку індивідуального професійного розвитку, яка містить складові елементи, які подані на рис.3.

Протягом року керівники підрозділів, спостерігаючи за поведінкою та роботою своїх підлеглих, повинні вносити відповідні записи до картки. У кінці звітного року керівники подають картки у відділ кадрів для подальшого аналізу та організації такого виду навчання, яке $€$ необхідним для конкретного працівника.

При формуванні основних складових картки індивідуального професійного розвитку необхідно враховувати особливості і професійні досягнення працівника. 


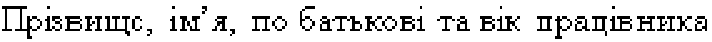

UiMe

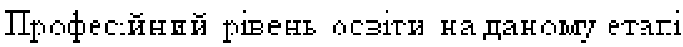

Посап三

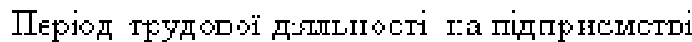

Cтұок прокодкення піпеицення кваліфікаці

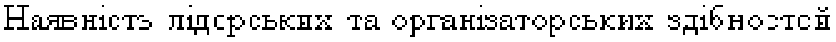

Скнльнтіс до навчання

Особлиэі поффесійн: эпібнисті

-Іерелів пғоблем у роботі

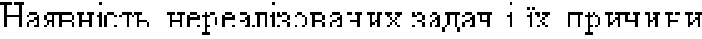

Рис. 3. Складові картки індивідуального професійного розвитку

Введення карток на підприємстві дає можливість підібрати для працівників той вид навчання, який $є$ необхідним для продуктивного виконання посадових обов'язків і допоможе їм максимально розкрити свій потенціал. Все це сприятиме кар'єрному росту працівників, що запобігатиме їх звільненню.

Окрім того, подальше вдосконалення механізму формування високорозвиненого кадрового потенціалу ДП «Березнівський лісгосп» передбачає створення мережевої взаємодії підприємства та навчальних закладів, яка допоможе ефективно поєднати науку, виробництво і не допускатиме подальше розпорошення кадрового резерву. У результаті такої кооперації підвищується конкурентоспроможність і продуктивність учасників мережі, зменшуються витрати, забезпечується зайнятість та консолідуються інтереси сторін.

Пропонується створити механізм підготовки власного кадрового резерву саме спеціалістів та службовців, використовуючи мережеву взаємодію підприємства та навчальних закладів, які наближені до підприємства територіально.

Реалізація механізму формування власного кадрового резерву ДП «Березнівський лісгосп» розпочинається з планування. Відділом 
кадрів визначається потреба в персоналі, яка залежить від обсягів виробництва, основних цілей підприємства та його стратегічного куpсy.

Наступний крок - залучення працівників. Визначившись у потребі в спеціалістах та службовцях, підприємство має надати запит до обраних навчальних закладів, для направлення випускників на ДП «Березнівський лісгосп».

Кваліфіковані спеціалісти та службовці повинні знати весь виробничий процес, починаючи з професійно-технічної або середньої спеціальної освіти і, закінчуючи вищим навчальним закладом.

ДП «Березнівський лісгосп» має надати запит із запланованою кількістю працівників до навчальних закладів. Серед студентів цих навчальних закладів обираються найталановитіші та успішні. Навчання для них оплачує ДП «Березнівський лісгосп». Із такими студентами укладається договір, за умовами якого після закінчення ВН3, вони мають працювати на підприємстві.

Окреслимо основні функції вищого навчального закладу, що входитиме до складу мережевої взаємодії:

1) планування навчального процесу в цехах, відділах та інших підрозділах підприємства;

2) організація виконання курсових та дипломних робіт, дослідницької роботи студенів за темами, що пов'язані з вирішенням науково-дослідницьких, проектних та виробничих завдань ДП «Березнівський лісгосп»;

3) організація науково-інформаційного обслуговування працівників підприємств;

4) підготовка спеціалістів за замовленням підприємства.

У свою чергу, ДП «Березнівський лісгосп» має взяти на себе наступні зобов'язання: надання студентам робочих місць на складах, цехах, дільницях для виконання ними всіх видів навчальної та науково-дослідної діяльності, а також для проходження виробничої практики; визначення тем для виконання студентами курсових та дипломних робіт, надання керівників дипломного та курсового проектування; фінансування науково-дослідної роботи, що виконується навчальним закладом на договірній основі; визначення тем пріоритетних досліджень для підприємства та передача їх до ВНЗ для подальшого вивчення.

Схема мережевої взаємодії підприємства та навчального закладу відображена на рис. 4. 


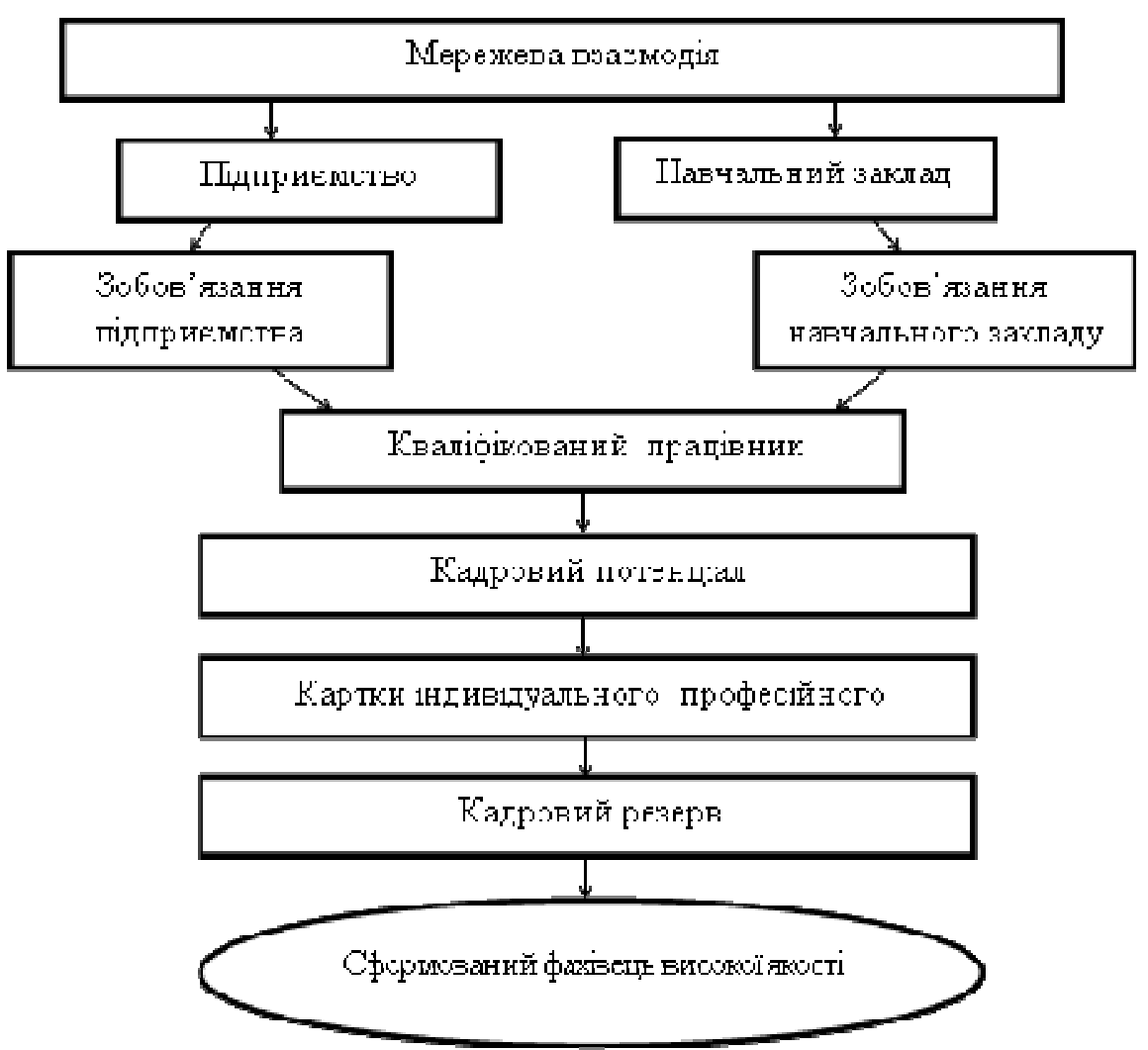

Рис. 4. Механізм формування мережевої взаємодії підприємства та навчального закладу

Наступним кроком у реалізації концепції маркетингу персоналу $€$ прогнозування кількості персоналу, що передбачає побудову середньострокового прогнозу для визначення кількості спеціалістів та службовців, яких потребуватиме ДП «Березнівський лісгосп». Саме прогноз дає можливість розрахувати витрати, які повинне буде понести підприємство за впровадження заходів щодо первинної підготовки працівників у навчальних закладах за договорами. Прогноз кількості працюючих на підприємстві, побудований за допомогою методу екстраполяції на основі абсолютного приросту (табл. 4).

Згідно прогнозу кадровий резерв на підприємстві має формуватися у межах 6-9 працівників. Що ж до чисельності спеціалістів та службовців, які будуть необхідні для підприємства за прогнозом, необхідно розрахувати вартість навчання 4 осіб. Оскільки, на місце звільнених з причин плинності працівників необхідно буде мати в резерві уже підготовлених кандидатів. Витрати на первинну підготовку на заміщення 1 посади спеціаліста або службовця у навчальних закладах у поточних цінах становлять понад 100 тис. грн. (без врахування первинних потреб (харчування та одяг)). 
Вибір претендента для навчання визначається на основі опрацювання карток індивідуального професійного розвитку.

Запровадження маркетингової концепції управління персоналом на ДП «Березнівський лісгосп», зокрема, через налагодження дії програми мережевої взаємодії підприємства та навчальних закладів, вимагає оцінки їі результатів. За експертними оцінками професійне навчання персоналу забезпечує зростання продуктивності праці щонайменьше на $2 \%$, що покриває витрати на професійну освіту та дає можливість отримати позитивний економічний ефект.

Таблиця 4

Прогнозування кількості персоналу ДП «Березнівський лісгосп»

\begin{tabular}{|c|c|c|c|c|c|}
\hline \multirow[t]{2}{*}{ Показники } & \multicolumn{5}{|c|}{ Роки } \\
\hline & 2017 & 2018 & 2019 & 2020 & 2021 \\
\hline $\begin{array}{l}1.0 б с я г и \\
\text { реалізованої } \\
\text { продукції, тис. грн }\end{array}$ & 114390 & 135432 & 156474 & 177516 & 198558 \\
\hline $\begin{array}{l}\text { 2. Річна продуктив- } \\
\text { ність праці одного } \\
\text { працівника, } \\
\text { тис. грн./особу (ПП) }\end{array}$ & 554,76 & 743,45 & 932,14 & 1120,83 & 1309,52 \\
\hline $\begin{array}{l}\text { 3.Середньооблікова } \\
\text { чисельність } \\
\text { працівників, осіб }\end{array}$ & 206 & 182 & 168 & 158 & 152 \\
\hline \multicolumn{6}{|l|}{3 них: } \\
\hline керівники & 16 & 15 & 13 & 13 & 12 \\
\hline $\begin{array}{ll}\text { спеціалісти } & \text { та } \\
\text { службовці } & \end{array}$ & 25 & 22 & 20 & 19 & 18 \\
\hline робітники & 165 & 145 & 135 & 126 & 122 \\
\hline $\begin{array}{l}\text { 4.Чисельність } \\
\text { працівників, } \\
\text { звільнених } 3 \text { причин } \\
\text { плинності }\end{array}$ & 47 & 42 & 39 & 36 & 35 \\
\hline \multicolumn{6}{|l|}{ з них: } \\
\hline керівники & 4 & 3 & 3 & 3 & 3 \\
\hline $\begin{array}{l}\text { спеціалісти } \\
\text { службовці }\end{array}$ & 6 & 5 & 5 & 4 & 4 \\
\hline
\end{tabular}

Висновки. Соціальна доцільність реалізації маркетингу персоналу спричинена високою ймовірністю налагодження хорошого зв'язку працівників з підприємством, що краще мотивуватиме їх до ефективнішої і результативнішої роботи. Разом з тим, існує суттєва 
економія на відборі і адаптації нових спеціалістів і службовців.

Основні результати реалізації запропонованої програми удосконалення маркетингу персоналу ДП «Березнівський лісгосп» підтверджують соціальну та економічну доцільність застосування маркетингу персоналу, використовуючи навчання та розвитку власного персоналу, що відобразиться на зростанні продуктивності праці та зниженні рівня плинності. Зокрема, все те, що допоможе сформувати міцний штат працівників, спрямованих на високі результати роботи і ефективну діяльність підприємства у майбутньому.

1. Управление персоналом организации : учебник / под ред. А. Я. Кибанова. М. : ИНФРА-М, 1997. 512 с. 2. Кармазін В. А., Пермінова О. О., Маркетинг персоналу як фактор реалізації кадрової стратегії підприємства. URL: http://www.kntu.kr.ua/doc/zb_20(1)_ekon/stat_20_1/25.pdf (дата звернення: 01.11.2018). 3. Колпаков В. М. Маркетинг персоналу : навч. посіб. К. : МАУП, 2006. 408 с. 4. Бугалтерська звітність ДП «Березнівський лісгосп» за 20142016 pp. 5. Статистична звітність ДП «Березнівський лісгосп» за 2014-2016 pp. 6. Головко А. С. Теоретико-методичний зміст категорій «трудовий потенціал», «кадровий потенціал» та «трудові ресурси». Вісник Хмельницького національного університету. 2010. № 3. Т. 2. 7. Гринкевич С. С., Гураль Н. Р. Дослідження взаємозв'язку трудового та кадрового потенціалів. Економічний форум. 2011. http://www.nbuv.gov.ua/portal/Soc Gum/Ekfor/2011 3/54.pdf (дата звернення: 01.11.2018).

\section{REFERENCES:}

1. Upravlenye personalom orhanyzatsyy : uchebnyk / pod red. A. Ya. Kybanova. M. : YNFRA-M, 1997. 512 s. 2. Karmazin V. A., Perminova 0. 0., Marketynh personalu yak faktor realizatsii kadrovoi stratehii pidpryiemstva. URL: http://www.kntu.kr.ua/doc/zb_20(1)_ekon/stat_20_1/25.pdf (data zvernennia: 01.11.2018). 3. Kolpakov V. M. Marketynh personalu : navch. posib. K. : MAUP, 2006. 408 s. 4. Buhalterska zvitnist DP «Bereznivskyi lishosp» za 2014-2016 rr. 5. Statystychna zvitnist DP «Bereznivskyi lishosp» za 2014-2016 rr. 6. Holovko A. S. Teoretyko-metodychnyi zmist katehorii «trudovyi potentsial», «kadrovyi potentsial» ta «trudovi resursy». Visnyk Khmelnytskoho natsionalnoho universytetu. 2010. № 3. T. 2. 7. Hrynkevych S. S., Hural N. R. Doslidzhennia vzaiemozviazku trudovoho ta kadrovoho potentsialiv. Ekonomichnyi forum. $2011 . \quad$ № 3. http://www.nbuv.gov.ua/portal/Soc_Gum/Ekfor/2011_3/54.pdf (data zvernennia: 01.11.2018).

Рецензент: д.е.н., професор Савіна Н. Б. (НУВГП) 
Beztelesna L. I., Doctor of Economics, Professor, Prokopchuk N. M., Master (National University of Water and Environmental Engineering, Rivne)

\section{SOCIO-ECONOMIC EXPEDIENCE OF PERSONNEL MARKETING APPLICATION IN STRATEGIC MANAGEMENT OF ENTERPRISE}

This article assumes that the marketing of personnel is a type of management activity in the enterprise. It is proved that the use of marketing personnel requires cost. The sources of coverage of staffing needs are highlighted and emphasis is placed on the expediency of using active and internal resources.

The results of realization of business strategies and personnel management of the enterprise are analyzed. The conducted economic analysis of the results of activity of the state enterprise 'Bereznivsky forestry' in 2014-2016 shows the successful implementation of the business strategy. It was established that the implementation of the strategy of personnel management of the enterprise is consumer and unsatisfactory, as the characteristic is high fluidity. It is determined that the greatest turnover of staff is illustrated by the age group of 1535 years old men who have incomplete and basic higher education and work as workers. It was established that the company does not engage in the marketing of its own personnel, namely its development through training, retraining and advanced training. It is through the implementation of personal marketing activities for its own employees that the company can build an effective personnel management.

It is proposed to start the process of practical introduction of personnel marketing at the enterprise through the system of individual professional development cards, which will enable the process of retraining and professional development of specialists to be comprehensive and qualitative. To establish network interaction with educational institutions that train specialists for the needs of the enterprise. The mechanism of formation of network interaction of the enterprise and educational institution is constructed. The task of each participant of such network interaction is determined. To calculate the needs and volumes of marketing personnel, a medium-term forecast for the number of staff was built. Estimated cost of training 1 specialist in the system of higher education to meet the needs of the enterprise in the formation of personnel reserve. 
The proposed program for improving the marketing of the staff of the State Enterprise 'Bereznivskyi forestry' confirms the social and economic feasibility of training and development of its own personnel, which will be reflected in the growth of labor productivity and decrease of personnel turnover, which will help to form a strong staff of employees aimed at high results of work and effective activity of the enterprise. the future.

Keywords: personnel, marketing, enterprise, card of individual professional development, network interaction, personnel potential, personnel reserve, planning.

Безтелесна Л. И., д.э.н., професор, Прокопчук Н. М., магистр (Национальный университет водного хозяйства и природопользования, г. Ровно)

СОЦИАЛЬНО-ЭКОНОМИЧЕСКАЯ ЦЕЛЕСООБРАЗНОСТЬ ПРИМЕНЕНИЯ МАРКЕТИНГА ПЕРСОНАЛА В СТРАТЕГИЧЕСКОМ УПРАВЛЕНИИ ПРЕДПРИЯТИЕМ

Отражено социально-экономическую целесообразность применения маркетинга персонала на одном из предприятий лесного хозяйства. Проанализированы расходы и пути покрытия потребности В персонале за счет собственных источников. Построен практический механизм реализации маркетинга персонала, включая налаживание сетевого взаимодействия предприятия и учебных заведений, формирование карточки индивидуального профессионального развития работника, построение планов профессионального роста персонала.

Ключевые слова: персонал, маркетинг, предприятие, карта индивидуального профессионального развития, сетевое взаимодействие, кадровый потенциал, кадровый резерв, планирование. 